\title{
IMPACT OF COVID-19 ON SOCIAL COHESION AND ROLE OF MUSLIM COMMUNITIES TO TACKLE THE CHALLENGE Muhammad Umar Riaz Abbasi ${ }^{1 *}$, Tariq Ejaz ${ }^{2}$, Shamshad Akhtar ${ }^{3}$ \\ ${ }^{1 *} \mathrm{Ph}$.D. Scholar, National University of Modern Languages, Islamabad, Pakistan; ${ }^{2}$ Assistant Professor Air University Islamabad, Pakistan; ${ }^{3}$ Lecturer, University of Central Punjab, Lahore (Sialkot), Pakistan. \\ Email: "umerriazabbasi@numl.edu.pk
} Article History: Received on $25^{\text {th }}$ March 2021, Revised on $14^{\text {th }}$ April 2021, Published on $23^{\text {rd }}$ April 2021

\section{Abstract}

Purpose of the study: This research is focused on examining the impact of Covid-19 on societal social cohesion. Furthermore, the role of Muslim communities in tackling the challenges has also been investigated in detail.

Methodology: The discussed research is conducted by detailed analysis of the related literature. This paper is thus based upon the secondary data gathered from different sources including newspapers, articles published in journals, books, and reports from diverse non-governmental, and governmental organizations.

Main Findings: The biggest challenge for the globe at this crucial time is isolation and social distancing as it has impacted the world at a large level. Social interaction is vital for human existence, and its absence leads to stressed, anxious, and depressed life. Also, it hampers the economic growth of the state. Muslim communities have been afflicted with various difficulties in the context of their religious matters due to this pandemic. They have even paused their major religious tasks like Pilgrimage, congregations, and Namaz-e-Jummah to prevent the people from deadly consequences of the pandemic.

Applications of this study: This study can be useful in examining the impacts of COVID-19 disease on social cohesion. Furthermore, it can be used in understanding the concept of Social cohesion according to the point of view of the Quran and Sunnah. Additionally, it aids in exploring the steps taken by the Islamic world in tackling this disease and its impacts on social togetherness.

The originality of this study: This is a comprehensive study on the impacts brought about by Covid-19 on social cohesion. Also, the role played by Muslim societies in handling the social challenges imposed by Covid-19 is the focus of this study. Moreover, this study encompasses the Islamic way and guidance by Quran and Sunnah to tackle the pandemic situations.

Keywords: Coronavirus, Covid-19, Social Cohesion, Muslim Communities, Challenges.

\section{INTRODUCTION}

It is very difficult to acquire the social development goals without social cohesion as it assists in keeping the communities together. Practically, taking all the required measures to fight poverty, gender, and status inequalities, confronting the discriminations, and escalated progress is important. Social cohesion is very important to achieve social development goals, with its aim to build peace among inclusive societies, attaining the right to use justice for everyone, along with the establishment of efficient, liable, and comprehensive societies at every stage (Jedwab et al., 2020). Enhancements of the social interactions amongst variable communities as well as reinforcing the social convention among the townspeople together with the state are preconditions for each of these purposes. Social cohesion is an obscure and challenging notion. Experts usually recognize it depending upon its dimensions, vertical and horizontal both. The horizontal facet explains the relationships, interactions, and trust amidst the citizens in society through the groups inclusive of uniqueness or various other social parameters, such as class, creed, or race. Vertical social cohesion encompasses confidence between the citizens of the society and the government. This is inclusive of the trust in economic, social, or political leaders, processes, and institutions. Processes include gain access to justice, budgeting, elections, taxation, and the provision of public services (Slobodin \& Cohen, 2020). Generally, it is accepted that there are economic, security, political, and social aspects of social cohesion. Covid-19 has also largely affected the current progressive cooperation process work plans, priorities, delivery, and activities in delicate contexts. The partner states are anticipated to redirect their contributions as well as priorities in the coming time. That is why, considering the modification is highly required in every developmental cooperation plans, particularly for the unstable states, alongside the humanitarian-progression-peace relationship. Resistance and reaction mechanisms ought to be investigated systematically in ongoing ventures and programs. This encompasses not just comprehending the impacts of coronavirus disease on the development of social cohesion but the existing injustices, facets, and perceptions related to disparities regarding access to health programs, income, livelihood chances, and employment also (Leshem et al., 2020).

All of these factors are potentially severe and immediate dispute causing features that may also destabilize social cohesion together with peace and development. Muslim parties, leaders, governments, and military leaders responded in different manners to erupt Covid-19 causing coronavirus throughout the Middle East as well as North Africa. Islamic State for Iraq and Syria (ISIS) directed its disciples to avoid travelling to Europe, which is the main centre of this pandemic disease. Fundamentalist Sunni members of the clergy mentioned conspiracy principles that accused atheists as 
well as Shiites of prompting the global pandemic. Some members of the clergy in Jordan, Morocco, and Egypt even pondered if the pandemic was Punishment from Allah for non-believers. Moderate Islamic groups cooperated with the governments alongside offering the disciples practical suggestions on the ways of preventing the pandemic ailment. Muslim community introduces a wide range of Islamic parties, governments, and movements. At its one tip, they are inclusive of modest political parties like Ennahda, which is a self-declared democratic group of Muslims and since 2011, Tunisia's confederacies governments. On the other tip are the radical jihadi groups like Al Qayeeda and ISIS. Between the two are the governments which are headed by the Islamists groups like in Turkey or Saudi Arabia where Shariah is the law. The following discussion thus entails the impact of Covid-19 on social cohesion along with the rundown of the measures adopted by Muslim communities to confront the related challenges.

World health organization proclaimed Covid-19, which is a coronavirus, as an ailment on 11 of February 2020. This is a respiratory disorder that damages an individual's health as a whole. The first Covid-19 case was stated in China for the first time by the end of 2019. Coronavirus disease was declared to be pandemic by the world health organization in March 2020 as a pandemic ailment. Fever, cough, breathing difficulties, and sore throat, all are symptoms of coronavirus disease. Man being a social animal relies much upon social interactions as well as relations as they are mandatory for man's existence. The newly discovered coronavirus together with the measures necessary to control it has caused a challenge to the interactions between the communities and the members living in them globally.

\section{The rationale of the study}

The biggest challenge for the globe at this crucial time is isolation and social distancing as it has impacted the world at a large level. social interaction is vital for human existence, and its absence leads to stressed, anxious, and depressed life. Also, it hampers the economic growth of the state. The Muslim community has been afflicted with various difficulties in the context of their religious matters due to this pandemic disease.

\section{The objective of this study}

To examine the impacts of Covid-19 disease on social cohesion. Also, the goal of this conducted research is to comprehend the steps taken by the Muslim leaders to cope with the challenges posed by Covid-19.

\section{LITERATURE REVIEW}

\section{- What is social cohesion?}

Social cohesion is something that is defined as the measure or extent of solidarity, interaction, and connectedness among various groups in society. Functionally, social cohesion is directed towards the identification of two fundamental facets including the extent of the connection between the communities' citizens and the interaction amongst the members living in that particular community (Fonseca et al., 2019). It derives from the democratic struggles to establish a dynamic economy, national identity, and social balance, along with the target of building the structure of equity, and equality, retaining the inclinations of unrestrained economic expansion, and preventing social damages. Social cohesion is fundamentally a social phenomenon to consolidate the multiplicity of public spirit via reduction of inequality, injustice, social, and economic disparity, and damages within the society. It highlights the requirements of the people for their personal development along with the attribute of connectedness. Furthermore, social cohesion is subjected to the linkage of economic efficacy, individual freedom, fair distribution of the basic resources, social justice, common measures to resolve disputes, and pluralism (Calo-Blanco et al., 2017). Social cohesion is defined in the context of positive interactions within the society and/or community. It connects people. Efforts for the wellbeing of the society members, fighting the exclusion as well as marginalization, creation of connectedness, promotion of trust, and confidence, and growth are among the notable attributes of social cohesion (Delhey et al., 2018).

\section{- Significance of social cohesion in the religion of Islam}

Understanding the importance of social cohesion is based upon the capacity of the society to reveal internally against any ongoing problem, upon the inclination of an individual being the member of a particular society to collaborate as well as to be patient with other societal members via shared and/or universal values. By doing so, harmony together with prosperity can be maintained in multiracial, multi-religious, and multi-cultural states. Shariah is driven by certain values as it is all about norms and rituals. The Muslims need to understand that social cohesion coincides with the aims of shariah to preserve life along with the religion. Without social cohesion among the communities, hate, fanaticism, and intolerance arise which ultimately leads to violence. Each of these core tendencies and attributes may have jeopardized the conservation of life as well as religion because of the actions of few people who do not cooperate, understand, and tolerate the interpersonal and communal differences (Bin Ramlan, 2020). In Quran, in surah Al-Isra, verse 33, Allah has said:

\section{"And never assassinate the person whom Allah has forgiven, but except for the law" (Quran, Surah Al-Isra, verse 33)}

The importance of social cohesion in the religion of Islam is perfectly exemplified by the anarchic Madinah prior to the migration of Hazrat Muhammad Mustafa SAWW from Makkah. It has been mentioned in history the clans of Ous and Khizrij were in the continuous situation of a dispute with each other before Hazrat Muhammad Mustafa SAWW and 
Muhajireen arrived at Madinah from Makkah. The arrival of Hazrat Muhammad Mustafa SAWW resolved this conflict and brought about peace and brotherhood among the two clans of Ous and Khizrij. Furthermore, meanwhile, peace and brotherhood were established amidst Muhajireen and the Ansaar. In the state of Madinah, social cohesion among different religious communities was accomplished and scripted in a document which is called the Charter of Madinah or The Madinah Treaty in the recognition of the rights as well as duties of minor religious communities and by the construction of Masjid-e-Nabbawii SAWW as documented by Sheikh Sayeed Ramadan Al-Bautii (Peace Be Upon Him)(late) in Fiqh Siraah. A section from the Treaty of Madinah stated by Hazrat Muhammad Mustafa SAWW identifies the religious constitutional rights for minority groups:

"The community of the Jews from the clan of Banii Auff are among the community of the Muslims. For the community of Jews is their religion, and for the community of Muslims is their religion" (Ahmad, 2014).

The importance of the action of Hazrat Muhammad Mustafa SAWW for the establishment of social cohesion prior to the stabilization of finances is that social cohesion is the base of every single progress and development in the community. Undoubtedly, this action of Hazrat Muhammad Mustafa SAWW was followed by turning His SAWW attention towards the economic state of the Muhajireen in Madinah. This action is stated in 'Four examples of Prophetic guidance in coexisting with others, Principles and Objectives'- a book authored by Sheikh Ali Jumaa.

In Sahih Al-Bukhari, Anas ibn-e-Maalik RA reported that:

When, among the Muhajireen, Abdul Rehman bin-Auf arrived towards us, Hazrat Muhammad Mustafa SAWW developed a link of brotherhood amidst Saad bin Arabi (who belonged to Ansaar), who was a rich person and AbdulRehman bin Auf. Saad bin-Arabi said, "the Ansaar has the knowledge that I am most rich among the other members of Ansaar, therefore I will apportion my wealth in the two portions that are amidst me and you".

Not only Hazrat Muhammad Mustafa SAWW connected the above-mentioned people through the bond of brotherhood, but also, He SAWW connected His other companions, as evident in various other reports of hadith.

Another example is stated by Ibn Sayeedin-Naas and Ibn-Hisham in Uyoonul Al-Athaar and Prophetic history respectively, in which the names of other friends are sated together with the other residents of Ansaar in Madinah. It is known that Hazrat Muhammad Mustafa SAWW mentioned 100 names-50 from the Ansaar, and the other 50 from Muhajireen. It was done with the intention that Muhajireen and Ansaar may work together to acquire financial dependence as well as stability. Also, it was done to prevent Muhajireen from depending on the charitable money of other people or laying off here and there without performing anything productive (Morni \& Khan, 2021). In Surah AlHashar, Verse number 9, Allah has stated the characteristic of the Ansaar people as:

"And the people who lived in Madinah and accepted the faith earlier to them. They love the ones who took refuge there, and do not desire anything for themselves, and give preference to the emigrants, even in the state of privation. And those who prevent themselves from greed will succeed" (Quran, Surah Al-Hashar, verse 9).

\section{METHODOLOGY}

This is a comprehensive study on the impacts brought about by Covid-19 on social cohesion. Also, the role played by Muslim societies in handling the social challenges imposed by Covid-19 is the main focus of this study. The discussed research is conducted by detailed analysis of the related literature. This paper is thus based upon the secondary data gathered from different sources including newspapers, articles published in journals, books, and reports from diverse non-governmental, and governmental organizations.

\section{DISCUSSION/ANALYSIS}

\section{- Social cohesion and COVID-19}

The global pandemic disease, Covid-19 has ravaged the entire globe. Enforcing the non-clinical rules and regulations to limit the spread of this deadly virus is a difficult procedure for many states. Developing countries such as Nigeria are immensely attacked with the tremendous duty of executing some of the guidelines related to Covid-19 to protect its population from this ailment. Numerous knowledge and skills experts have invested a large amount of time to examine the condition as it poses an impact on the different facets of life. A significantly considerable factor is the examination of the impact of Covid-19 on social cohesion in a state. Generally, most of the preventive and safety measures related to Covid-19 are anti-social because they are about maintaining social distance to avoid the spread of the virus. Human connectedness and activities which include physical interactions and visits have been halted by the state as well as federal governments. This is contrary to social cohesion, which refers to the degree of connectedness as well as solidarity among the members of the society (Dayrit \& Mendoza, 2020).

The main goal of social cohesion is the reduction of social, economic, and cultural inequities, and injustice. Achieving social cohesion at the community level has become very tough because of this disease. People are strictly and strongly advised to stay at their homes, and stay away from any kind of social engagement, interaction, and gathering. Ultimately, it affects the notion of community cohesion, that is the promotion of linkage and connectedness among the members of the community. Several methods of achieving social cohesion are inclusive of sports, worship places, campaigns, 
entertainment programs, schools, community outreaches, convention, and cultural programs. For example, the orientation program of NYSC i.e., the National Youth Service Corporation has been suspended. Because of this pandemic and the instructions being implemented, the moto of developing social cohesion within a state or any community is intensively threatened. Remarkably, social cohesion may also be improved because of pandemic (Borkowska \& Laurence, 2021). As the globe is fighting against the virus, people have started to find ways to adapt to the changes. People have been seen to engage in charity activities to assist needy ones in surviving the tough conditions caused because of pandemic (Nextier, 2020).

However, the pandemic has excessively affected black as well as other minor communities. Though, the government has provided ail to offer temporary support to helpless societies who are going through economic trials due to health, social, and economic inequalities, and prejudice. Not only black, but brown communities are suffering from psychological trauma as well. Social cohesion alleviates the adverse consequences of depression, loneliness, and alike causative factors of distress. Furthermore, social cohesion enhances the health of aged people and adults. Promotion of social cohesion to assist the helpless and make them cope with the health and mental challenges due to Covid-19 should be made possible by the organizations responsible for community development (Kim, 2020). Dr, Jane Kennedy who is the head of the research and data centre at Newham has stated the amazing reaction of the local community members and numerous volunteers. In Newham, social cohesion is already highly promoted and response to pandemic has influenced Newham to be more responsive and cohesive with the working partners. Nevertheless, the pandemic has caused many important challenges. States have been hit hard by this novel virus, with elevated mortality rates, specifically in European states, and many economic trials (Centre for Science \& Policy [CSP], 2020).

Numerous trials have been suffered by Iraq that has disturbed social cohesion. Pandemic has collapsed the country's economy. It has exacerbated standing and profoundly ingrained economic, security, political, and social challenges. The impact of Covid-19 on social cohesion signifies another root of stress among several others. It has nurtured an ordinary narrative that is anticipated to unify the communities just similar to the response of Iraq to ISIL i.e., an Islamic state in the Levant. This pandemic has excessively influenced marginalized and susceptible communities inclusive of women, aged, and adult people. Violence based on gender discrimination has increasingly been reported in many states (United Nations Development Program [UNDP], 2020). The outbreak of pandemic has affected every segment of the community population. Also, it specifically targets the most vulnerable groups of society, the people who are suffering from poverty, the people with older age, disabled persons, youth, and indigenous persons. Early investigation reports reveal that the health, as well as economic influences of the corona virus, are carried excessively by the poor community. For instance, people without a home, as they are not able to shelter themselves properly, and are intensively exposed to the health threat caused by the virus. Communities with no access to clean and hygienic water including migrants, displaced people, and refugees also continuously suffer excessively from the pandemic and the consequences caused by it, maybe due to constraint movement, restricted opportunities for employment, enhanced xenophobia.

There must be some standard policy to address the social catastrophe caused by Covid-19, otherwise, it would lead to rose exclusion, global unemployment, inequality, and discrimination in the medium as well as long term ( $\underline{\text { Spoonley et }}$

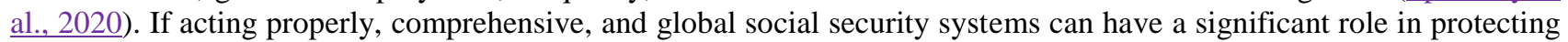
employers and in reduction of the prevailing poverty, as these systems can do it efficiently. These systems are responsible for the provision of fundamental income protection always, that is how they enhance the capacity of people to manage and conquer the shocks. On 23 March 2020, the General Secretary of the United Nations emphasized that we should assist and help the most susceptible- millions and millions of individuals who cannot protect themselves and their families. This is the basic attribute of human unity. Also, it is very important to fight the virus. It is high time to help the susceptible" during the launching program of Covid-19 Global Humanitarian response plan (UN department of Social \& Economic Affairs, n.d.).

\section{- Response plan of Muslim community to tackle the challenge}

The entire globe is facing a huge disruption of the lifetime, Muslims also across the entire globe are also struggling with the consequences of the pandemic disease. However, the theological, cultural, and spiritual dimensions of Islam offer the Muslims numerous ways of surviving.

Muslims possesses comparatively large family systems and tries to maintain kinships. Hazrat Muhammad Mustafa SAWW inspired the Muslims to maintain strong bonds among their families. Also, the Holy Quran encourages Muslims to be kind with relatives in Surah Nahl, verse 90, and in Surah Al-Isra, to treat the elders with empathy. These Islamic teachings have led the Muslims to live together in a single-family unit or they keep on visiting their large families. Numerous Muslims find it difficult to implement the phenomenon of social distancing at the one tip and prefer to live close to their families and other relatives for comfortable and supportive living. In Australia, Muslims have been imposed tight restrictions as they are banned to visit their families and relatives (Basri, 2020). The foremost challenge that Muslims had to face due to the outbreak of the Pandemic is not to shake hands, though it is considered to be Sunnah in Islam, and hugging the friends and relatives, especially in the mosques and in the gatherings of Muslims.

One or two weeks after the implementation of these restrictions in March, the hugging was restricted, which made Muslims feel miserable. Personal hygiene is another important aspect to prevent coronavirus that is very natural for 
Muslims. Organizations and health experts are directed towards promoting personal hygiene to curb the spread of Covid19. Washing the hands repeatedly for a minimum of 20 seconds has been largely emphasized. For a long, Islam encourages personal hygiene since ever. In Surah Al-Mudassir, verse 4, Allah instructed the Muslims to maintain the clothes tidy, and that "Allah loves the clean people" has been stated in Surah Al-Baqarah, verse 222. 14 centuries back, Hazrat Muhammad Mustafa SAWW highlighted that cleanliness is half of the faith and instructed the Muslims to wash hands before as well as after eating, take a shower minimum of one in a week (also necessarily after marital relation), brush the teeth every day, and to purify the nails and their private parts. Furthermore, Muslims are obligated to do ablution before every prayer (Ozalp, 2020).

\section{Shutting Down of mosques and disturbance in Friday rituals}

Muslims (especially men) are commanded by Allah to perform the congregational prayers necessarily in the mosquesthe sacred and holy place. This instils a feeling of being in the aura of the holy place and a feeling of surrounded by other believing Muslims. Accordingly, the Muslims line up in the rows with their shoulders touching to that of others. This arrangement is very precarious in the time of the pandemic. Almost, all the mosques are closed due to pandemic disease. Other congregational prayers are comparatively less challenging to skip, however, skipping the Jumma prayer in the Mosque is highly challenging for the Muslims. prayer of Friday is very important to be performed in the mosque. It starts with the initial 30 to 60 minutes of the sermon and then the congregational prayer of just 5 minutes in the afternoon (Thomas \& Barbato, 2020). Restricting the Jumma prayer at a global level has never happened since this thing was done by Hazrat Muhammad Mustafa SAW in $622 \mathrm{CE}$, just after He migrated to the state of Madinah from oppression suffered by Him and His followers in Makkah. The first one who banned the Jumma prayers was Iran on the $4^{\text {th }}$ of March, 2020. Whereas the countries including Turkey as well as Indonesia struggled to continue the prayers if Jumma to be held in the mosques by making the social distancing an obligation. Though it did not continue for that long time and the whole Muslim community soon shut down the mosques even for the congregational prayers. It was fortunate for the Muslims as the shutting down of the mosques did not mean that they cannot perform daily prayers in all.

In the religion of Islam, a person's prayers and the actions of worship have an important role as compared to the religious tasks performed altogether. Muslims are allowed to perform their congregational prayers, at any place, (but must be clean of any impurity). Women mostly pray at home, as it is more rewarding for them. The gap that occurred due to the ban on Friday prayers in the mosque has been compensated by the Jumma sermons that are offered online. Two among the five pillars of Islam are fasting during Ramzan and the pilgrimage to Makkah at least once every year (only for those who can afford it financially) (Attaftazani et al., 2020). During the holy month of Ramzan, the Muslims who are fasting are commanded not to eat or drink anything, also, they are instructed to refrain from marital relations from dawn to dusk. This part of Ramzan is not influenced by the Covid-19. But the routine congregational prayers that are Taraweeh are highly affected. Also, breaking of fasts (Iftaar) is affected, as most of the Muslims invites their friends and relatives on iftaar. However, in western states, non-believers are also invited to such gatherings. Islamic associations declared the cancellation of such gatherings at the dinners during the pandemic $(\mathrm{Bi}, 2020)$.

Eid is the festival celebration of Muslims as Ramzan ends. The government also has limited the families to stay at home (Hussain \& Castro. 2020). The impact of Covid-19 on the pilgrimage is comparatively huge. Umrah is an optional Islamic pilgrimage that happens all around the year, which intensifies as soon as Ramzan approaches. As Iran is considered as the hot spot of this deadly virus, the Saudi Arabia government banned the entry and exit from and to Iran and other pilgrims as well, earlier on the $27^{\text {th }}$ of February 2020. The major pilgrimage (Hajj) was occurred by the end of July in 2020. Though the outbreak of the virus was anticipated to get slowed down by July, yet the proceeding of pilgrimage by 2 million people from almost every state around the world was thought to flame the spread of the virus again and bring the second wave of the pandemic. So, the Saudi Arabia government decide to cancel Hajj in 2020. Never in the history of 14 centuries of Islam, Hajj was entirely cancelled, not even because of war or the unsafe roads, but for the first time, Hajj got banned, due to pandemic (McManus et al., 2020). The concepts of Muslims regarding the virus have been doctrinal.

Muslims have a belief that Allah has created this entire universe and continuously governs all worldly affairs. This notion directs towards the concept that the emergence of coronavirus is actively created by Allah. Therefore, according to other religious communities, this coronavirus has emerged as a punishment for the wrongdoers, therefore it is useless to fight against it and everyone must trust Allah (tawakkul) that He will save the right acts doing people. This belief and such thoughts may assist in the reduction of fear possessed by the pandemic at a very large scale, yet it can make everyone unreasonably complacent as well. The majority among the Muslims oppose this passive approach by making an argument that though the emergence of this dangerous virus is not under the control of humans, the spread of this ailment is. They prompt us that Hazrat Muhammad Mustafa SAWW directed a man who left his camel untied as he had trust in Allah: "first you should tie your camel and then leave it to Allah". Hazrat Muhammad Mustafa SAWW took medical therapy and advised his disciples to sought medical therapy by saying that Allah has not created any disease without making a remedy to treat it, except old age (CA et al., 2020). Additionally, Hazrat Muhammad Mustafa SAWW instructed about quarantine by saying that if someone comes to know about the spread of plague on a particular land on earth, he/she must not enter that place, or if the plague spread out inland when you are living there, you should not leave 
that piece of land. Sometimes, we are afflicted with a trial inevitably. The Holy Quran guides the believers to see the difficulties of life as a test from Almighty- as in Surah Al-Baqarah, verse 153-157 Allah says that these are the temporary trials to reinforce us.

This perspective makes the Muslim to be resilient in difficult times, with enough strength (Algaissi et al., 2020). During such a situation, the health of some people is lost, not only this, but few lose their jobs, and even life. Hazrat Muhammad Mustafa SAWW stated that the one who lost his property during the difficult times would be given the reward equal to that of charity. And if someone dies because of the pandemic, would be ranked as the martyr of paradise. As the entire Muslim community is suffering from the pandemic, they wonder about the change in their living practices afterwards (Templeton et al., 2020). The government of Vietnam imposed restrictions at international levels to curb the imported coronavirus cases from highly afflicted states, during the initial stage of the pandemic outbreak. This was done also to control the spread of disease and for reducing the magnitude of the ongoing epidemic. Moreover, preventive strategies alongside the readiness to bound the disease at the national level controlled the spread of the pandemic. Also, the government took immediate preventive steps in contrast to Pakistan and the United Arab Emirates, to restrict the incoming corona cases, also to refrain from the local spread of the virus. Pakistan and UAE delayed the decision of restricting travel and implementing lockdown, which caused the spread of disease even faster (Jabeen et al., 2020). The governments of Pakistan with the help of the partner organizations have developed a bi-spindle approach to counter the pandemic situation- highlighting struggles to control and reduce the spread of disease and considering the consequent humanitarian, social, and economic impacts.

The governmental plans, specifically the Covid-19 National Action plan, three initiatives were supported at an international level to consider the pandemic situation and its aftermaths: the first initiative is the SPRP that is strategic preparedness \& response plan. This plan has a goal to stop virus transmission. This initiative is largely supported by the World Health Organization. Assistance and related actions in this context are tracked through the Covid-19 partner's platform. The second initiative is the shared responsibility and global unity: response to the social and economic effects of coronavirus is highly recommended to reduce the socio-economic aftermaths of the disease. It is established by the UN (United Nations). The third initiative is the Integrated Humanitarian Response plan, the humanitarian country team in Pakistan is establishing an integrated response plan under the supervision of the humanitarian coordinator to focus on the human impact of the pandemic situation on the susceptible group of people. This aimed approach creates assistance for the government under humanitarian actions and plans (Noreen et al., 2020).

\section{RECOMMENDATIONS}

Though maintaining social cohesion in disputed zones is very difficult during times of pandemic, yet it is not impossible. Identification of the people who can assist in peace-making is important. Also, the ones who can resolve the conflicts and establish social cohesion in this very crucial time is highly significant. Particularly, government and the related organizations that are contributing to the creation of social cohesion among the different societies must search for novel measures to overcome the pandemic-caused challenges. Social cohesion is promoted by the apparent sense of the trustworthiness of governmental issues by its people. That is why the government must take into account that the palliatives and every other government plan related to the disease are equally instigated with no favor or marginalization of the particular group. Despite this, the disease and its precautionary measures may have an impact on social cohesion. However, with appropriate planning as well as envisaging platforms that are already present which encourages cohesion, the government can protect the disease impacts and provide vistas that can help in cohesion. Attainment of sustainable development goals and the aim of keeping everyone together would be difficult without social cohesion. It is evident that Covid-19 is exacerbating numerous existing economic, security, political, and social issues, so it is important to seek measures that can reduce the further uncomfortable effects. Nationally, there is a need to develop a suitable strategic approach to promote national social cohesion. Also, meanwhile quick, and short-term responsive strategies must be adopted to combat pandemic and its impact on societal relations. A strategic approach needs to cover every segment of the state without leaving anyone behind.

\section{CONCLUSION}

Clear comprehending of the related dimensions of social cohesion is important. By now, according to the social damages caused by the pandemic disease crisis, it is very critical than ever. To tackle the challenges caused by the pandemic, many imperative steps have been taken by the Muslim communities. This pandemic disease has affected uncountable lives in several states. This has led to serious public concern with many measures being taken to control its transmission. This is inclusive of the introduction of the plan control order along with the complete lockdown across the globe. Worship places have been closed such as mosques, though it has caused discomfort to Muslims.

\section{LIMITATION AND STUDY FORWARD}

Though this study entails the Islamic and societal concept and significance of social cohesion. Moreover, it delineates the impact of the ongoing pandemic situation on social cohesion. Still, the urge of maintaining brotherhood bonds, economic development, and sustenance policies, as well as effective preventive plans needs to be discussed. 


\section{ACKNOWLEDGEMENT}

I would like to express gratitude to Mr. Tariq Ejaz for his great support which was really influential in shaping my research methods and critiquing my results. I also thank Shamshad Akhtar for his valuable contribution to the literature review and collected data. I would like to thank my friends, classmates, colleagues, and research team for a cherished time spent together in the libraries, and in social settings. My appreciation also goes out to my family and friends for their encouragement and support all through my Research.

I would also like to thank Maj Gen Jaffar Hussain, Rector National University of Modern Languages, and the administration staff for their technical support on my Research.

\section{AUTHORS CONTRIBUTION}

Muhammad Umar Riaz Abbasi has generated the main idea of the research, worked on research methodology, and developed the tool for data collection. Being $1^{\text {st }}$ Author Mr. Abbasi led from the front as research team mentor to formulate everything in the right direction with a futuristic approach. Tariq Ejaz has planned the data analysis and analyzed the data. Shamshad Akhtar has worked on literature review and collected the data.

\section{REFERENCES}

1. Ahmad, K. (2014). A short note on the Medina Charter. Retrieved from https://www.ashtoncentralmosque .com/wp-content/uploads/2014/07/A+Short+Note+On+The+Medina+Charte r.pdf

2. Algaissi, A. A., Alharbi, N. K., Hassanain, M., \& Hashem, A. M. (2020). Preparedness and response to COVID-19 in Saudi Arabia: Building on MERS experience. Journal of infection and public health, 13(6): 834838. https://doi.org/10.1016/j.jiph.2020.04.016

3. Attaftazani, M. I., Zhafira, A. R., \& Purnama, I. (2020, November). Indonesian Muslims Response to Covid-19 from the Perspective of Ash'arite Theology. In Ushuluddin International Conference (USICON) (Vol. 4).

4. Basri, H. (2020). Religious Community Responses to COVID-19: Case Study on Muslim Small Community. International Journal of Psychosocial Rehabilitation, 24(8), 10439-10446.

5. Bi, S. (2020). Racialisation of Rescuehood: Contextualising British Muslims stuck abroad during COVID-19 pandemic. https://www.researchgate.net/publication/341575190_Racialisation_of Rescuehood_Contextualisin g British Muslims stuck abroad during_COVID-19 pandemic

6. Bin Ramlan, U. A. R. (2020, January 29). The Importance of Social Cohesion in Islam. Retrieved from https://muslim.sg/articles/the-importance-of-social-cohesion-in-islam

7. Borkowska, M., \& Laurence, J. (2021). Coming together or coming apart? Changes in social cohesion during the Covid-19 pandemic in England. European Societies, 23(sup1), S618-S636. https://doi.org/10.1080/146166 96.2020.1833067

8. CA, C. M., MA, S., MF, M. T., \& SAK, S. A. H. (2020). Muslims Responses to Pandemics: Lessons from the Best Generation. IIUM Medical Journal Malaysia, 19(2). https://doi.org/10.31436/imjm.v19i2.1609

9. Calo-Blanco, A., Kováŕík, J., Mengel, F., \& Romero, J. G. (2017). Natural disasters and indicators of social cohesion. PloS one, 12(6), e0176885. https://doi.org/10.1371/journal.pone.0176885

10. Centre for science and policy. (2020, June 24). The State of Social Cohesion During Covid-19 - Networks of evidence and expertise for public policy. Retrieved from http://www.csap.cam.ac.uk/news/article-socialcohesion-seminar/

11. Dayrit, M. M., \& Mendoza, R. U. (2020). Social cohesion vs COVID-19. International Journal of Health Governance, 25(3), pp. 191-203. https://doi.org/10.1108/IJHG-03-2020-0022

12. Delhey, J., Boehnke, K., Dragolov, G., Ignácz, Z. S., Larsen, M., Lorenz, J., \& Koch, M. (2018). Social cohesion and its correlates: A comparison of Western and Asian societies. Comparative Sociology, 17(3-4), 426-455. https://doi.org/10.1163/15691330-12341468

13. Fonseca, X., Lukosch, S., \& Brazier, F. (2019). Social cohesion revisited: a new definition and how to characterize it. Innovation: The European Journal of Social Science Research, 32(2), 231-253. https://doi.org/10.1080/13511610.2018.1497480

14. Hussain, A., \& Castro, C. (2020). American Muslims and COVID-19. https://vimeo.com/408949355

15. Jabeen, A., Ansari, J. A., Ikram, A., Abbasi, S. H., Khan, M. A., Rathore, T. R., \& Safdar, M. (2020). Comparison of actions taken by Pakistan, United Arab Emirates and Vietnam for COVID-19 prevention and control. Global Biosecurity, 1(4).

16. Kim, J. (2020). The role of social cohesion in addressing the impact of COVID-19 on mental health within marginalized communities. Local Development \& Society, 1(2), 205-216. https://doi.org/10.1080/26883597. .2020 .1829985

17. McManus, S., D'Ardenne, J., \& Wessely, S. (2020). Covid conspiracies: misleading evidence can be more damaging than no evidence at all. Psychological Medicine, 1-2. https://doi.org/10.1017/S0033291720002184

18. Morni, F., \& Khan, A. (2021). Mudharabah as a Conduit for Social Cohesion among Vulnerable Women. International Journal of Islamic Economics, 2(2), 90-99. https://doi.org/10.32332/ijie.v2i2.2270

19. Nextier SPD. (2020, June 22). Social and Community Cohesion Amidst of COVID-19 Pandemic - Nigeria. Retrieved from https://reliefweb.int/report/nigeria/social-and-community-cohesion-amidst-covid-19-pandemic 
20. Noreen, N., Dil, S., Niazi, S., Naveed, I., Khan, N., Khan, F., Tabbasum, S., \& Kumar, D. (2020). COVID 19 pandemic \& Pakistan; limitations and gaps. Global Biosecurity, 1(4). https://doi.org/10.31646/gbio.63

21. Ozalp, M. (2020, April 2). How coronavirus challenges Muslims' faith and changes their lives. Retrieved from https://theconversation.com/how-coronavirus-challenges-muslims-faith-and-changes-their-lives-133925

22. Spoonley, P., Gluckman, P., Bardsley, A., McIntosh, T., Hunia, R., Johal, S., \& Poulton, R. (2020). He oranga hou: social cohesion in a post COVID-19 world. Koi Tū: The Centre for Informed Futures.

23. Templeton, A., Guven, S. T., Hoerst, C., Vestergren, S., Davidson, L., Ballentyne, S., Madsen, H. \& Choudhury, S. (2020). Inequalities and identity processes in crises: Recommendations for facilitating safe response to the COVID-19 pandemic. British Journal of Social Psychology, 59(3), 674-685. https://doi.org/10.1 $111 /$ bjso. 12400

24. Thomas, J., \& Barbato, M. (2020). Positive religious coping and mental health among Christians and Muslims in response to the COVID-19 pandemic. Religions, 11(10), 498. https://doi.org/10.3390/rel11100498

25. UN Department of Economic and Social Affairs. (n.d.). Everyone Included: Social Impact of COVID-19. Retrieved from https://www.un.org/development/desa/dspd/everyone-included-covid-19.html

26. UN Development Programme. (2020, November 15). Impact of COVID-19 on social cohesion in Iraq - Iraq. Retrieved from https://reliefweb.int/report/iraq/impact-covid-19-social-cohesion-iraq

27. Quran, Surah Al-Isra, verse 33

28. Quran, Surah Al- Hashar, verse 9

29. Quran, Surah Al-Bararah, verse 153-157

30. Slobodin, O., \& Cohen, O. (2020). A culturally-competent approach to emergency management: What lessons can we learn from the COVID-19? Psychological Trauma: Theory, Research, Practice, and Policy, 12(5), 470. https://doi.org/10.1037/tra0000790

31. Jedwab, R., Khan, A. M., Damania, R., Russ, J., \& Zaveri, E. D. (2020). Pandemics, poverty, and social cohesion: lessons from the past and possible scenarios for COVID-19. Mimeo.

32. Leshem, E., Afek, A., \& Kreiss, Y. (2020). Buying time with COVID-19 outbreak response, Israel. Emerging infectious diseases, 26(9), 2251. https://doi.org/10.3201/eid2609.201476 